Piotrowski D. (2014). The financial aspect of intergenerational solidarity from the point of view of the senior. Copernican Journal of Finance \& Accounting, 3(2), 111-126. http://dx.doi. org/10.12775/CJFA.2014.021

\author{
Dariusz Piotrowski* \\ Nicholas Copernicus University
}

\title{
THE FINANCIAL ASPECT OF INTERGENERATIONAL SOLIDARITY FROM THE POINT OF VIEW OF THE SENIOR
}

Key words: intergenerational solidarity, public finance, social expenditure.

J E L Classification: A13, H51, H55, 015.

\begin{abstract}
Many currents in economics put an emphasis on the social aspect of management. Recommendations are formulated with regard to using resources having in mind the satisfaction of needs by the current and future generations. The economic crisis has shown the bad state of public finance of many countries and put into question the existence of intergenerational solidarity in the financial terms. The lack of balance between generations is related with a high level of public debt and social obligations of the state burdening chiefly the young generation. The study aims at examining how seniors understand the nature and financial expressions of intergenerational solidarity. The supplementary objective is to learn the seniors' views on the need and directions of reforms of the Polish public finance, in particular in the scope of pension and health benefits. Objectives were achieved and research hypotheses verified through the critical analysis of literature on the issue and on the basis of the author's survey among the members of the Torun Third Age University and the Kujawsko-Dobrzyński Third Age University. The results achieved allow for a conclusion that the vast majority of respondents understand the notion of intergenerational solidarity incorrectly are not aware of the scale of financial obligations which were put on the younger generations, and put too much emphasis on their own input into the increase of our country's wealth. It has
\end{abstract}

Date of submission: August 1, 2014; date of acceptance: September 25, 2014.

* Contact data: darius@econ.umk.pl, Faculty of Economic Sciences and Management, Nicolaus Copernicus University, Gagarina 13a, 87-100 Toruń, Poland, phone: 566114634 . 
also turned out that seniors very often present a demanding attitude in the field of the state's social expenditure and do not take into consideration the financial capabilities of the state.

Translated by Dariusz Piotrowski

\title{
FINANSOWY ASPEKT SOLIDARNOŚCI MIĘDZYPOKOLENIOWEJ Z PUNKTU WIDZENIA SENIORA
}

Słowa kluczowe: solidarność międzypokoleniowa, finanse publiczne, wydatki socjalne.

Klasyfikacja J E L: A13, H51, H55, 015.

\begin{abstract}
Abstrakt: Wiele nurtów w ekonomii akcentuje społeczny aspekt gospodarowania. Formułowane są zalecenia dotyczące wykorzystania zasobów z myślą o zaspokajaniu potrzeb przez obecne i przyszłe pokolenia. Kryzys gospodarczy ukazał zły stan finansów publicznych wielu krajów i poddał w wątpliwość istnienie solidarności międzypokoleniowej w ujęciu finansowym. Brak równowagi międ zy pokoleniami ma związek z wysokim poziomem długu publicznego oraz zobowiązaniami socjalnymi państwa obciążającymi głównie młode pokolenie. Celem pracy było zbadanie zrozumienia przez seniorów istoty i finansowych przejawów solidarności międzypokoleniowej. Jako cel uzupełniający przyjęto natomiast poznanie poglądów seniorów na temat potrzeby i kierunków reform finansów publicznych Polski, w szczególności w zakresie świadczeń emerytalnych oraz zdrowotnych. Realizacja celów i weryfikacja hipotez badawczych nastąpiła w drodze krytycznej analizy literatury przedmiotu oraz w oparciu o wyniki autorskiego badania ankietowego przeprowadzonego wśród członków Toruńskiego oraz Kujawsko-Dobrzyńskiego Uniwersytetu Trzeciego Wieku. Uzyskane wyniki pozwoliły stwierdzić, iż przeważająca część respondentów niepoprawnie rozumie pojęcie solidarności międzypokoleniowej oraz nie jest świadoma skali zobowiązań finansowych, którymi obarczono młodsze pokolenia, zbyt mocno natomiast akcentuje własny wkład we wzrost bogactwa naszego kraju. Okazało się także, że seniorzy bardzo często wykazują postawę roszczeniową w obszarze wydatków socjalnych państwa nie licząc się z możliwościami finansowymi kraju.
\end{abstract}

\section{INTRODUCTION}

As an answer to growing criticism of an economic system based on the principles of free market competition, trends have emerged in the theory of economics which refer to the high economic efficiency achieved in the conditions of respecting the rules of social justice and environmental protection. The welfare state concept which has emerged within liberalism reduces the socially negative effects of human activity in the capitalist system through distribution of income leading to providing equal opportunities for the development of economically weaker individuals (Sadkowski 2010, 168-171). On the other hand, 
the ordoliberalism-based social market economy assigns the state a function of creating institutions which ensure the implementation of social solidarity postulates. This concept skilfully combines economic freedom of an individual with justice and responsibility in actions, and from another perspective, the high efficiency of a market system with the state's provision of social security to citizens (Szulczewski 2011, 181-184). The idea of sustainable development, advocated in the recent years, puts equal emphasis on thinking in the categories of solidarity and common good. Generally, the presented currents advocate for assessing the effects of actions taken in the economic sphere from the point of view of benefits and costs for the current and future generations. The cited idea of intergenerational solidarity assumes mutual help between the representatives of different generations and such use of resources which takes into consideration the chances of subsequent generations to meet their needs (Kulińska-Sadłocha 2011, 33-42).

The debt crisis in countries and the exposed necessity to introduce public finance reforms require shifting accents of social and economic sustainable growth to the financial aspects of intergenerational solidarity. Ensuring balance in that field is supported by limiting the budget deficit, the public debt and the amount of financial liabilities of the state in respect of the implemented social policy (Męczyńska 2010, 191; Reinhart, Rogoff 2011, 1676-1706; Wisensale 2013, 21-29).

\section{RESEARCH METHODOLOGY AND THE COURSE OF THE RESEARCH PROCESS}

Today's seniors are mostly people born during the post-war baby boom, who have lived most of their lives in the People's Republic of Poland. They also participated in the transformation of the Polish economy from a socialist model characterised by low market self-regulation and high control of the state over the economy to the social order based on market freedom and democracy (Gilejko 2008, 107-111). The views and attitudes of seniors presented and analysed in this work result from the fact they were functioning in two different economic systems and account for the fact that the representatives of the older generation appear in a dual role, i.e. the creators of the conditions of life and development of the younger generations and the main beneficiaries of the state's social policy.

The main objective of the work is to examine how seniors understand the nature and financial expressions of intergenerational solidarity. The supplementary objective is to learn the seniors' views on the need and directions of 
reforms of the Polish public finance, in particular in the scope of pension and health benefits. The study adopted two research hypotheses:

- H1: The burdening of the younger generation with financial obligations of the older generation is overlooked by the majority of the surveyed seniors.

- H2: Seniors are characterised by low awareness of the amount of financial burdens passed on to the future generations resulting from an improper social policy of the state.

Objectives were achieved and research hypotheses verified through critical analysis of literature on the issue and the elaboration of material gathered during the author's survey. The survey was conducted among the members of the Toruń Third Age University and the Kujawsko-Dobrzyński Third Age University in May 2014. The selection of persons to the study population was deliberate. The overall number of respondents was 97, with 76 participating in the survey in Toruń and 21 in Aleksandrów Kujawski. The participants constituted a high (about 30\%) proportion of members of both associations. The survey questionnaire the respondents were to fill in comprised open questions and single- or multiple-choice questions.

\section{THE FINANCIAL ASPECT OF INTERGENERATIONAL SOLIDARITY}

The life-cycle model refers the economic behaviour of an individual to the change of their age. It covers the pre-production stage, production stage, and post-production stage. Each stage is characterised by a different degree of personal and financial independence (Jurek 2012, 61). When analysing the life-cycle model from the point of view of public finance, it is clearly visible that the older generation constitutes a bigger burden for the state then the younger one. This happens because the costs of the care for the elderly are socialised, whereas funding the expenditures of the young generation usually rests on the family (Jurek 2012, 78).

Analysing the financial aspects of intergenerational dependency, it should be noted that the older generation is in a privileged position, but at the same time a position requiring greater responsibility for the consequences of the decisions made regarding the younger part of the society. It was the older generation that created the system and used to influence the shape of the social and economic policies of the state years ago (Neck, Sturm 2008, 2-4). The mechanism described in the W.D. Nordhaus's model indicates a big risk of choos- 
ing a social policy of the state leading to unfavourable results in the long term, manifested by high financial burdens of the subsequent generations (Tomczyk 2011, 81). Therefore, the younger generation, instead of acting as a beneficiary, is often obliged to act as the payer and a critical reviewer of the previouslymade decisions.

The dependencies described may lead to social conflict, as the representatives of different generations have conflicting objectives and interests (Price 1997, 109; Walczak-Duraj 2010, 287-291). In the situation of limited financial resources of the state a dilemma arises regarding the choice between financing economic development in view of the younger part of the society, or social benefits addressed at the elderly (Uryszek 2009, 99-105).

\section{SPHERES OF PUBLIC FINANCE WITH PARTICULAR REFERENCE TO THE NOTION OF INTERGENERATIONAL SOLIDARITY}

The functioning of the society is connected with meeting individual and collective needs. The needs declared by the whole society or by a considerable part of it are met by providing public or social goods financed solely or mostly from public funds (Wernik 2011, 31-33). One of the basic needs is the sense of social security of the citizens. The state ensures this security through financing social expenditure covering pension and disability benefits, healthcare, or social aid (Adamiak, Chojnacka, Walczak 2013, 19-24). The connection between generations is most visible in the pay-as-you-go pension system, whose other name - intergenerational contract - best describes its idea. Less visible intergenerational dependencies, but no less serious with regard to scale, occur in the healthcare system. This is because it is mainly young people who finance state expenditure in that matter, using the benefits only in a limited scope.

The lack of balance of the benefits and burdens for each generation, somewhat inscribed in the state social expenditure system, requires limiting financial demands formulated by the generation of beneficiaries that are contrary to the idea of intergenerational solidarity (Zacher 2009, 171). Having this in mind, it can be assumed that the social expenditure of the state, which is financed from a part of the current tax revenue and the privatisation of state property, does not violate the postulate of intergenerational solidarity, as each generation has a right to receive that part of the nation's wealth which it has produced itself. The senior generation may also count on the help from younger people under the rule of reciprocity as it has provided it itself in the past. The situa- 
tion is different when in order to finance the needs of the older generation, the state needs to borrow for the account of the younger of future generations. The expectation that the country will finance expenditures exceeding its current capabilities is unethical and contradictory to the idea of intergenerational solidarity. Excessive expenditure leads to budget deficits and, in consequence, to the increase of public debt (Lane 2012, 49-65; White Paper 2012, 9-13).

\section{FINANCIAL HERITAGE OF THE SENIOR GENERATION}

In the opinion of the author, the negative outcomes of the actions of the older generation outweigh the financial benefits obtained by the younger generations, and they result from the public debt from the period of the People's Republic of Poland, low quality and utility of the property left and current and future social burdens of the state towards the seniors.

The Gierek ${ }^{1}$ decade was the only period of prosperity in the times of socialism and at the same time a period of huge borrowings of the Polish state. The debt incurred by the eldest generation still burdens the public finance as its repayment has only been deferred due to rolling. When estimating the actual scale of the inherited burdens, the amount of foreign debt, valued at the end of 1980s at over USD 40 million (Bałtowski, Miszewski 2006, 154), should be translated into PLN taking into consideration the purchasing power of the dollar, which was then higher than today.

The huge amount of debt incurred could be justified if the quality and utility of the assets left to the younger generations was high. In most cases, it has not been so. Enterprises in Poland in the declining years of communism were ineffective, underinvested and burdened with overemployment.

The financial picture of the state left by the eldest generation is completed by the expenditure on social obligations of the state. Although in the period of economic downturn of socialism there were and still are not enough funds in the earmarked funds, the state needs to pay pensions, disability pensions and finance health care. In the last years subsidies to the social security system amounted to PLN 50-55 billion each year (Sprawozdania z wykonania budżetu 2011-2014). The fact that the younger generation is excessively burdened due to benefits paid by the state to the seniors results in part from unfavourable

${ }^{1}$ First Secretary of the ruling Polish United Workers' Party in the People's Republic of Poland in the years 1970-1980. 
demographic tendencies, but its primary source is legal regulations. Benefits paid out within KRUS [Agricultural Social Insurance Fund] are only marginally financed by the insured, the rest is covered by the state, i.e. the younger generations. On the other hand, high subsidies to the Social Insurance Fund arise from a big number of privileges resulting in decreasing the actual age of retirement and from the manner of calculating the amount of benefit which allows taking into consideration the premiums deducted in the selected years of employment, most beneficial for the current seniors.

Another field of social expenditure, health service, also requires state subsidies. The manner of financing it, limiting the inflow of funds from outside the public sector, in connection with widespread expectations regarding using innovative medicines and modern medical procedures are the source of a growing public debt (Kubot 2011, 177-196). Expectations expressed with regard to the Polish health service should consider the fact that the amount of premiums in respect of health insurance deducted for an entire lifetime most often totals at around PLN 100-150 thousand and is not enough to cover the costs of all benefits, even of standard quality, whereas the Polish state cannot afford to co-finance state-of-the-art medical procedures to all citizens.

\section{SELECTED ASPECTS OF INTERGENERATIONAL SOLIDARITY - RESULTS OF THE EMPIRICAL STUDY}

This work presents selected results of the study (presented in graphic or descriptive form), which allowed to verify the assumed research hypotheses. The first one, concerning burdening the young generation with the liabilities of the older generation, was verified with the use of questions regarding the definition, understanding of the notion of financial intergenerational solidarity and the scale of financial burdens passed on to the younger generation. The surveyed persons were asked to express their attitude to the following phrase: Intergenerational solidarity in the financial aspect is a situation when the young generation, through deducted premiums and taxes paid, finances the benefits of the older generation. In the supplementary question, the respondents were asked to indicate the relation between financial benefits and burdens resulting from the activities of the older generation felt by the representatives of the younger generation. The obtained results were presented in charts 1 and 2 . 
Chart 1. Consent to the proposed definition of financial intergenerational solidarity

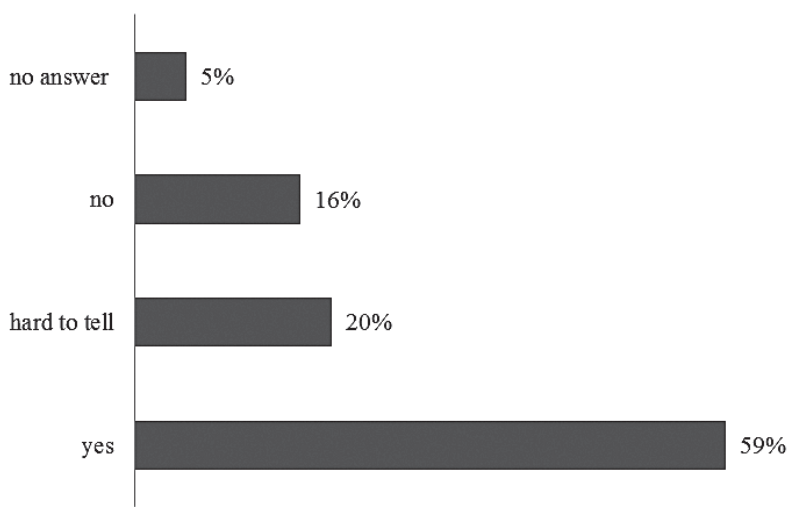

S o u r c e : own survey, $\mathrm{N}=97$, single choice.

When analysing chart 1 , it can be noted that the vast majority of persons, i.e. 57 (59\% of total) consented to the wording of the proposed definition. This definition, however, does not correspond with the conditions of balance which are included in the concept of intergenerational solidarity as it places the representatives of the older generation in a privileged position. The respondents did not notice financial interdependencies between the generations. This fact is confirmed by the answers given to the second question (chart 2). As many as $80 \%$ of the surveyed did not consider in their deliberations or attributed little importance to the financial burdens generated by the older generation at the expense of the younger one. 
Chart 2. The amount of financial burdens resulting from the activities of the older generation in relation to the younger generation

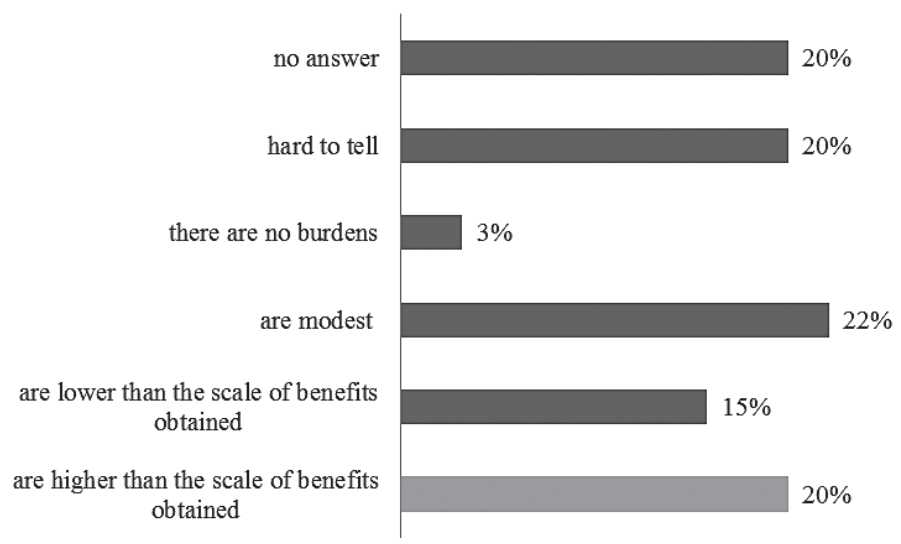

S o u r c e : own survey, $\mathrm{N}=97$, single choice.

The subsequent results refer to the issues of public finance, with particular attention paid to the notion of crisis and reforms. Answers to five questions in that scope were presented below.

Chart 3. The need and effects of the Polish public finance reform

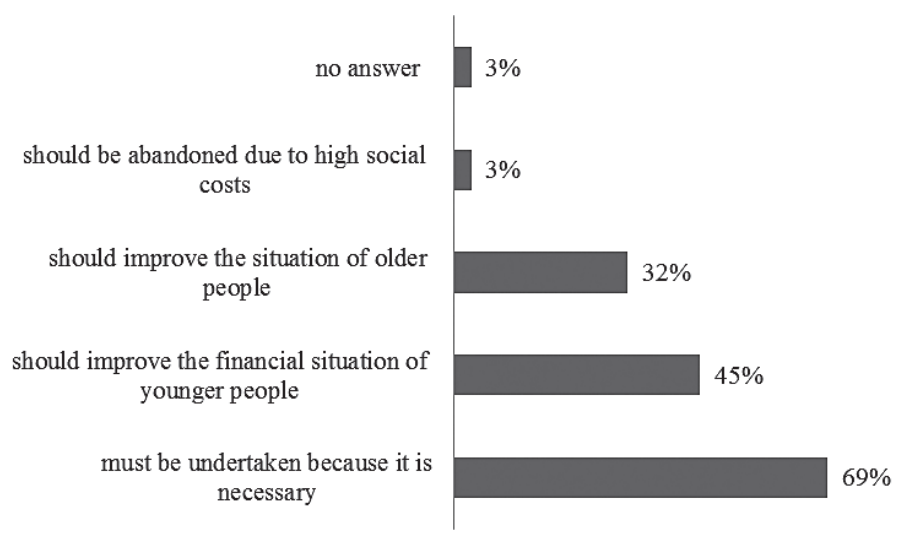

S o u r c e : own survey, $\mathrm{N}=97$, double choice at most.

Optimism stems from the fact that the need for reforms and the need for directing them at improving younger people's situation is noticed (chart 3). How- 
ever, it is hard to combine the desire to improve both the situation of the younger and older, i.e. all citizens, expressed in $20 \%$ of cases, with the indication in the next question of excessive state expenditure as the main reason of the bad situation of public finance by $80 \%$ of respondents.

Excessive state expenditure leads to deficits, these in turn lead to the increase of debt. The question regarding the types of state expenditure with the most influence on the increase of public debt in Poland was left unanswered by as many as $48 \%$ of the surveyed persons. In the next question, $45 \%$ of the respondents did not indicate the spheres of public finance in need of reform. Moreover, the persons who did answer the above questions, identifying the sources of excessive debt and spheres in need of improvement - administration, health service, pension system (privileges), financing national defence could not, in most cases, indicate remedial actions.

Chart 4. The culpable for the difficult situation of Greece

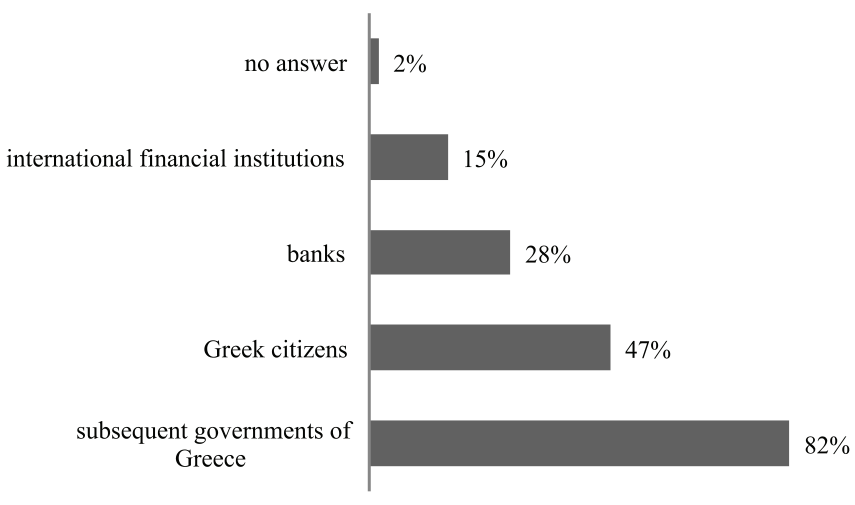

S o u r c e : own survey, $\mathrm{N}=97$, double choice at most.

The most severe effect of a state's financial problems is its bankruptcy. Based on the case of Greece, the study tried to obtain opinions regarding the culpable for the situation (chart 4). The most, $82 \%$ of indications concerned the subsequent governments of Greece, $47 \%$ the Greek citizens, and the actions of banks were named as the cause of Greece's problems in $28 \%$ of cases. Blaming the government for the problems of the state may be treated as a form of escape from one's own responsibility. However, part of the surveyed showed aware- 
ness of the fact that it is the citizens who, by choosing their representatives, take partial responsibility for the current and future situation of the state finance and the burdens for future generations. This is confirmed by the fact that the two first indications we very often chosen together.

The state social policy is implemented through expenditure, part of which is financed with debt. Thus resulting liabilities of the state must therefore be considered in the analyses of the phenomenon of intergenerational solidarity in the financial aspect. The results presented below refer to the attitudes and opinions of respondents in the scope of pension benefits and health care financing.

The answers obtained in the subject of sources of funds after reaching retirement age indicate that over a half of the surveyed people see a need to take up work or use savings gathered during the period of professional activity (chart 5). Therefore, they are not counting only on the benefit which, in the opinion of almost all of them, is too low and/or too low in comparison to the premiums deducted (chart 6). The question of how people who base their household budgets only on the gradually decreasing financial benefits from public funds manage to support themselves in retirement is an open one (Szumlicz $2011,144-145)$. The picture of the views with respect to social insurance is completed by the respondents' reception of the decision to increase and level the retirement age. In response to that question, $42 \%$ of persons treated this action as necessary, $17 \%$ as good, and $45 \%$ as bad.

Chart 5. Sources of funds after reaching retirement age

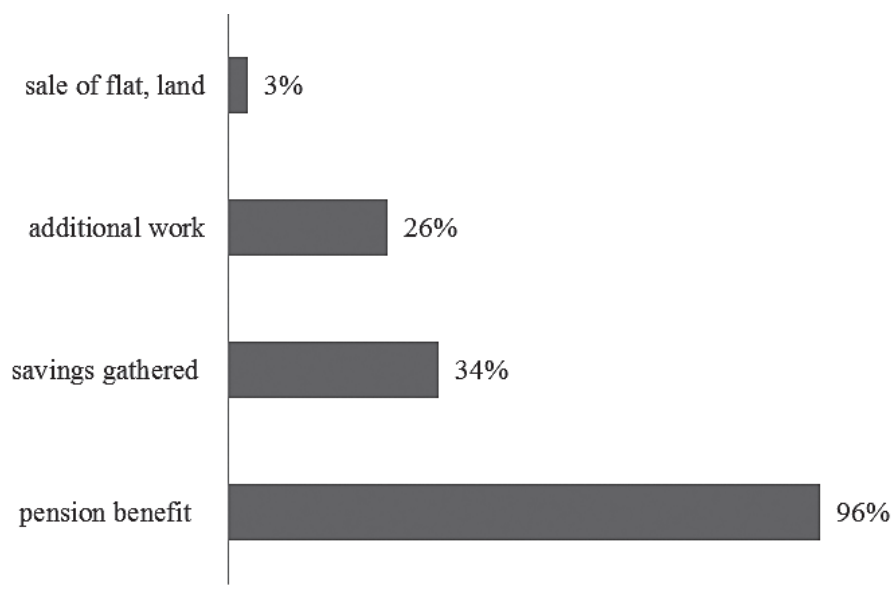

S o u r c e : own survey, $\mathrm{N}=97$, multiple choice. 
Chart 6. The assessment of the amounts of pensions paid

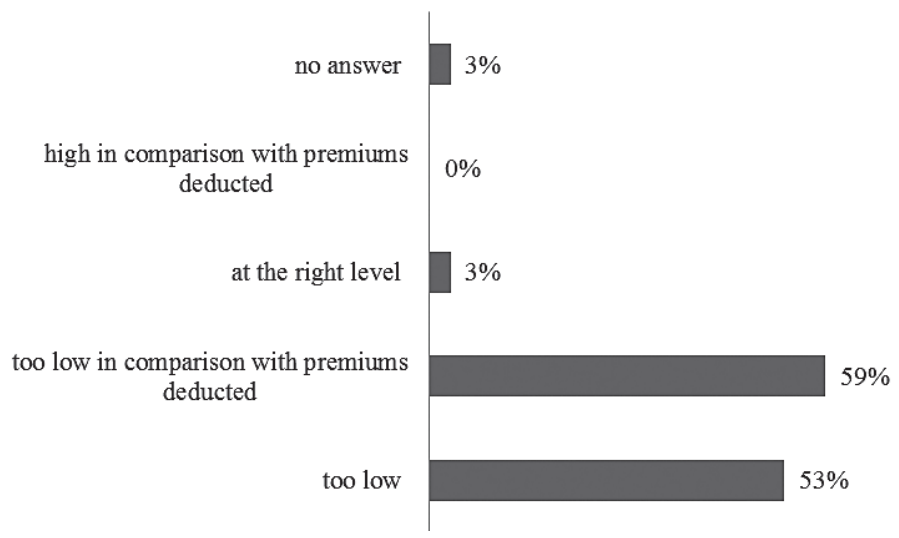

S o u r c e : own survey, $\mathrm{N}=97$, double choice at most.

The mostly critical assessment of the pension reform, in connection with an erroneous conviction that the older generation has earned higher pensions then it is receiving, indicates thinking in the categories of own interest or benefits for the older generation without taking into account the financial consequences affecting the younger generation. Such attitude contradicts intergenerational solidarity in the financial aspect.

The last of the examined spheres was the financial aspects of the functioning of health service. The author tried to determine the knowledge and opinions of the respondents on the basis of answers given to three questions.

The answers received in the scope of limits of medical services should be assessed negatively in the context of intergenerational solidarity. As many as $91 \%$ of the elderly people indicated the need to increase the availability of medical services, forgetting that these limits are a consequence of too scarce funds in the public health service. The expected growth of the number of services may occur when the system acquires additional funds in the form of increased budget subsidy to the National Health Fund, which would result in a rise of the public debt, which in turn would have a negative impact on labour costs and would burden the representatives of the younger generation. 
Chart 7. The appropriateness of the functioning of medical services' limits determined by the National Health Fund

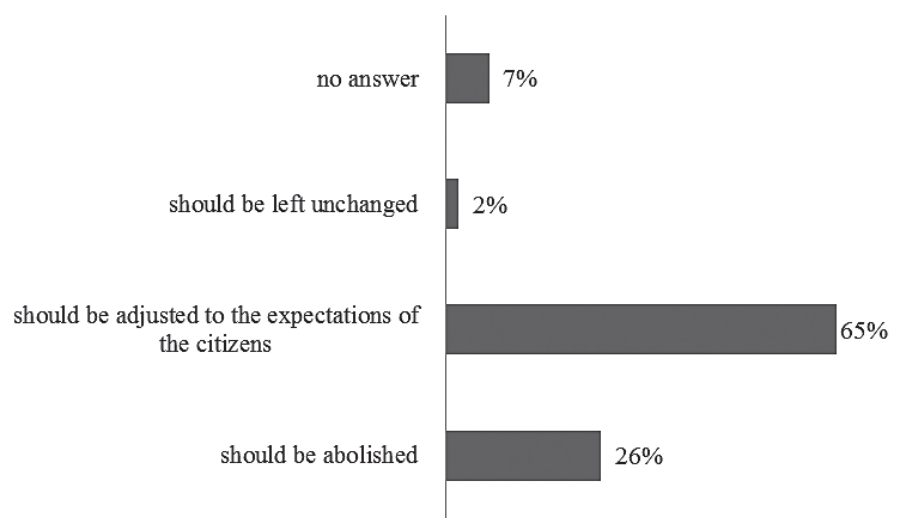

S o u r c e : own survey, $\mathrm{N}=97$, single choice.

The problems of the Polish health service result from bad system solutions and organisational errors, but their primary basis is financial. The expectation for an improvement in the situation of the health service requires the knowledge of the financial aspects of its functioning, including regarding the costs of medicines, equipment and medical procedures. In response to the question regarding the costs of a visit to the doctor to receive basic examination and a prescription, $67 \%$ of the respondents stated that they amount to PLN 0 . The last question aimed at finding whether the surveyed have knowledge of the costs of purchasing modern medical equipment. The question concerned the number of incubators which can be bought for the sum of health insurance premiums deducted during the lifetime of an average citizen of our country. The right answer being at most one, only $26 \%$ of answers took into consideration the market prices. In $53 \%$ of cases no answer was given. The lack of knowledge of the costs of medical services, emerging from the presented results, in connection with the scale of demands put forward, makes the declarations of caring for the life quality of the younger generation doubtful, as an increase in the state's financial burdens limits development opportunities of the younger part of the society. 


\section{CONCLUSIONS}

The received research results helped to positively verify two hypotheses assumed in the work, and sadly, their overtone is unfavourable. Most of the seniors understood the idea of intergenerational solidarity incorrectly, as on the one hand they did not see the scale of financial obligations which burden the younger generations, and on the other hand they presented demanding attitudes in relation to the benefits provided within the social policy of the state. They formulated their opinions possessing scarce knowledge on the real costs of functioning of the system. The attitude of the seniors, which stands in contrast to the idea of intergenerational solidarity, can be justified only in part. During the period of real socialism, the representatives of the older generation did not receive adequate economic education, and at the same time they emerged from those times with the conviction that they have a right to expect social benefits at a satisfactory level from the state, forgetting the illusoriness of these promises.

Physical and mental disability, advancing with age, is not a justification for the demands towards the state. Contrary to common belief, the households of the seniors, relieved from the costs of raising children, are not among the poorest. When analysing the financial capabilities of the generation of the seniors, it should be considered that they had an opportunity to gather assets in the form of a flat or land at prices attractive from today's point of view. They can sell a part of this wealth to improve the quality of their lives, while remaining in compliance with the cultural patterns of our society regarding the issue of inheritance.

The seniors who are members of Third Age Universities are active and socially engaged people, and stand out against their generation. Therefore, one can require that they themselves see and educate the representatives of their own generation on the responsibility for the bad condition of state finance and influence the limitation of financial demands unjustified with their own input regarding pension benefits and health service and thus create conditions for development for the younger generations. 


\section{REFERENCES}

Adamiak S., Chojnacka E., Walczak D. (2013). Social security in Poland - cultural, historical and economical issues. Copernican Journal of Finance \& Accounting, 2(2), 19-24. http://dx.doi.org/10.12775/CJFA.2013.013.

Bałtowski M., Miszewski M. (2006), Transformacja gospodarcza w Polsce, Wydawnictwo Naukowe PWN, Warsaw, 154.

Gilejko L. (2008), Rynek i otoczenie instytucjonalne (socjologia makroekonomiczna), 107-111 [in:] J. Gardawski, L. Gilejko, J. Siewierski, R. Towalski, Socjologia gospodarki, Difin, Warsaw.

Jurek Ł. (2012), Ekonomia starzejącego się społeczeństwa, Difin, Warsaw, 61, 78.

Kubot Z. (2011), Rynek usług medycznych, [in:] Państwo i rynek. Obszary zawodności, U. Kalina-Prasznic (ed.), Gaskor, Wrocław, 177-196.

Kulińska-Sadłocha E. (2011). Idea zrównoważonego rozwoju a ordoliberalna koncepcja społecznej gospodarki rynkowej. Optimum. Studia Ekonomiczne, no. (4) 52, 33-42.

Lane P.R. (2012), The European Sovereign Debt Crisis. Journal of Economic Perspectives, 26 (3), 49-65. http://dx.doi.org/10.1257/jep.26.3.49.

Męczyńska E. (2010), Ordo. Ustrój równowagi, 191 [in:] Idee ordo i społeczna gospodarka rynkowa, E. Męczyńska, P. Pysz (ed.), PTE, Warsaw.

Neck R., Sturm J-E. (2008), Sustainability of public debt, The MIT Press, Cambridge, 2-4.

Price M. (1997), Justice between generations. The growing power of the elderly in America, Preager Publisher, Westport, 109.

Reinhart C.M., Rogoff K.S. (2011), From Financial Crash to Debt Crisis. American Economic Review, 101 (5), 1676-1706. http://dx.doi.org/10.1257/aer.101.5.1676.

Sadkowski Z. (2010), Liberalizm i pojmowanie roli państwa w gospodarce, 168-171 [in:] Idee ordo i społeczna gospodarka rynkowa, E. Męczyńska, P. Pysz (ed.), PTE, Warsaw.

Sprawozdania z wykonania budżetu państwa w latach 2010-2013 (2011-2014), Ministerstwo Finansów, Warsaw.

Szulczewski G. (2011), Odpowiedzialność w ujęciu etyki i etyki gospodarczej, 181-184 [in:] Etyka biznesu w perspektywie humanistycznej, G. Szulczewski (ed.), Oficyna Wydawnicza SGH w Warszawie, Warsaw.

Szumlicz T. (2011), Finansowanie systemu zabezpieczenia emerytalnego w świetle kryzysu ekonomicznego, 144-145 [in:] Finanse publiczne a kryzys ekonomiczny, A. Alińska, B. Pietrzak (ed.), CeDeWu Sp. z o.o., Warsaw.

Tomczyk E. (2011), Oczekiwania w ekonomii. Idea. Pomiar. Analiza, Oficyna Wydawnicza SGH w Warszawie, Warsaw, 81.

Uryszek T. (2009), Wpływ wydatków zdeterminowanych budżetu państwa na ograniczenia w zakresie finansowania zadań prorozwojowych w Polsce, 99-105 [in:] W poszukiwaniu efektywności finansów publicznych, S. Wieteska, M. Wypych (ed.), Wydawnictwo Uniwersytetu Łódzkiego, Łódź.

Walczak-Duraj D. (2010), Socjologia dla ekonomistów, PWE, Warsaw, 287-291. 
Wernik A. (2011), Finanse publiczne. Cele. Struktury. Uwarunkowania, PWE, Warsaw, 31-33.

White Paper. An Agenda for Adequate, Safe and Sustainable Pensions (2012), European Commission, Brussels, 9-13.

Wisensale S.K. (2013). Austerity vs. Solidarity: Intergenerational Conflict in the European Union. International Journal of Humanities and Social Science, 3(1), 21-29.

Zacher L.W. (2009), Gry o przyszłość - wielopodmiotowe i generacyjne, 171 [in:] Wyzwania ekonomiczne w warunkach kryzysu. Wybrane zagadnienia, I. Lichniak (ed.), Oficyna Wydawnicza SGH w Warszawie, Warsaw. 